\title{
Sex and acid phosphatase in childhood non-T lymphoblastic leukaemia
}

\author{
JS LILlEYMAN, JA BRITTON, BJ LAYCOCK, AND PJ SUGDEN \\ From the Department of Haematology, The Children's Hospital, Western Bank, Sheffield S1O 2TH, UK
}

\begin{abstract}
SUMMARY A semiquantitative assessment of blast cell acid phosphatase activity, expressed as a score, was made in 41 unselected children with newly diagnosed and untreated non-T acute lymphoblastic leukaemia (ALL). Despite a wide range of enzyme activity in both sexes boys had significantly higher scores than girls, and, in view of the known association between males and T ALL on the one hand, and between acid phosphatase and T ALL on the other, these findings raise the possibility that boys may have a predisposition to a type of pre-T ALL which could contribute to the as yet unexplained difference in prognosis between the sexes.
\end{abstract}

It is recognised that boys with acute lymphoblastic leukaemia (ALL) have a worse prognosis than girls, ${ }^{1-3}$ but whether this is due to a sex-based difference in response to a common disease or to an unrecognised sex-linked poor-prognosis type of ALL is not clear. That the latter might be the case occurred to us while performing routine stains for acid phosphatase in all new cases of ALL. Apart from noting that the blasts were strongly positive in $T$ ALL, which is known, ${ }^{4}$ we also observed that a significant amount of the enzyme was often present in non-T ALL and that boys seemed to have more than girls. In an attempt to verify this impression, we developed an objective blind enzyme-scoring system and applied this prospectively to an unselected group of untreated patients.

\section{Patients and methods}

The patients studied were newly diagnosed and untreated consecutive children with non-T ALL seen at the Sheffield Children's Hospital over a three-year period up to June 1979. The diagnosis was based on conventional clinical, morphological, and cytochemical criteria; T ALL was identified (and thus excluded) by the formation of sheep cell rosettes. All but eight patients were tested with a heteroantibody raised against non-T, non-B ALL cells (anti-ALL), ${ }^{5}$ and, in addition, 11 patients had

Received for publication 20 August 1979 the terminal deoxynucleotidyl transferase (TdT activity in the blast cells assayed. ${ }^{6}$

The patients were treated according to the appropriate Medical Research Council therapeutic trial of the time, those with white counts $>20.0 \times 10^{9} / 1$ and the one negro in the group receiving a more intensive regimen.

Acid phosphatase stains were performed on fresh unfixed bone marrow smears according to the technique of Goldberg and Barka. ${ }^{7}$ Slides so stained from all the patients were later assembled and coded so that no patient identity was apparent on the slide. An arbitrary scoring system similar to that for neutrophil alkaline phosphatase, based on colour intensity and distribution of enzyme product, was devised between two observers in which each positive cell was graded from 1 to 4 . Each observer independently scored 200 blast cells from each patient in ignorance of the patient's identity and the score recorded by the other observer. Each score was expressed as a value for 100 cells and represented the mean of both assessments. Where the score differed by more than 20 , the observers conferred and agreed on a mean. To check the reproducibility of the staining technique, slides from 20 of the patients, unfixed and kept at $-20^{\circ} \mathrm{C}$ since the day of diagnosis, were thawed, coded, stained, and scored 'blind' to be compared with scores obtained previously. Four children with T ALL were seen during the study period and were scored for comparison purposes only.

The difference between the mean acid phosphatase scores for the two sexes was assessed for significance by Student's $t$ test. 
Table 1 Acid phosphatase activity in non-T ALL-boys

\begin{tabular}{|c|c|c|c|c|c|}
\hline Patients & $\begin{array}{l}\text { Age at diagnosis } \\
\text { (years) }\end{array}$ & $\begin{array}{l}\text { Leucocyte count at } \\
\text { diagnosis }\left(\times 10^{9} / I\right)\end{array}$ & Acid phosphatase score & Anti-ALL & $\begin{array}{l}T D T \text { assay (units/10 } \\
\text { cells) }\end{array}$ \\
\hline GJ & 6 & $4 \cdot 4$ & 143 & ND & ND \\
\hline МH & 3 & $7 \cdot 0$ & 81 & 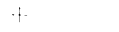 & ND \\
\hline DC & 2 & $11 \cdot 4$ & 126 & $\because$ & ND \\
\hline $\mathbf{S M}$ & 3 & $58 \cdot 0$ & 269 & + & ND \\
\hline CB & 5 & $8 \cdot 0$ & 47 & - & $10 \cdot 0$ \\
\hline AD & 7 & $5 \cdot 0$ & 79 & - & ND \\
\hline $\mathbf{J} \mathbf{M}$ & 3 & $4 \cdot 0$ & 162 & t & ND \\
\hline NM1 & 13 & $300 \cdot 0$ & 28 & & ND \\
\hline SA & 7 & 0.6 & 146 & - & ND \\
\hline NM2 & 2 & 0.7 & 68 & $\therefore$ & ND \\
\hline J B & 5 & $223 \cdot 0$ & 86 & $\div$ & ND \\
\hline GB & 5 & 8.0 & 37 & + & ND \\
\hline MC & 11 & $1 \cdot 5$ & 27 & \pm & ND \\
\hline LH & 7 & $7 \cdot 0$ & 91 & $\mp$ & 5.8 \\
\hline MO & 9 & 0.7 & 85 & $\div$ & $147 \cdot 7$ \\
\hline $\mathbf{J M}^{*}$ & 6 & 6.0 & 278 & + & $37 \cdot 6$ \\
\hline DF & 7 & 3.0 & 88 & + & $108 \cdot 0$ \\
\hline MK & 2 & $5 \cdot 0$ & 142 & + & ND \\
\hline Mean & 6 & $31 \cdot 0$ & 108 & & 74 \\
\hline
\end{tabular}

* Negro.

ND $=$ not done.

\section{Results}

During the period concerned, 41 children with non- $T$ ALL were seen, with ages ranging from 1 to 13 years; 21 were boys and five had white counts at diagnosis above $20.0 \times 10^{9} / 1$. There was one negro.

Acid phosphatase scores at diagnosis ranged from 5 to 278, and these are shown in Tables 1 and 2 (for boys and girls respectively) alongside age, white cell count at diagnosis, anti-ALL positivity, and TdT levels. There was a mean score of 108 for the boys and 62 for the girls; the difference is significant $(P<0.02)$. The four patients with T ALL not in the study group had scores ranging from 284 to 367 .

Scores differed between the two observers by more than 40 in only eight cases, all of which had scores $>100$. There was good correlation between the scores from the slides stained at diagnosis and the scores from the 20 slides obtained at diagnosis but stored frozen and unfixed $(r=+0 \cdot 81)$, although

Table 2 Acid phosphatase activity in non-T ALL-girls

\begin{tabular}{|c|c|c|c|c|c|}
\hline Patients & $\begin{array}{l}\text { Age at diagnosis } \\
\text { (years) }\end{array}$ & $\begin{array}{l}\text { Leucocyte count at } \\
\text { diagnosis }\left(\times 10^{9} / I\right)\end{array}$ & Acid phosphatase score & $A n t i-A L L$ & $\begin{array}{l}\text { TDT assay (units } / 10^{*} \\
\text { cells) }\end{array}$ \\
\hline TW & 4 & $10 \cdot 5$ & 108 & ND & ND \\
\hline DG & 4 & $40 \cdot 0$ & 14 & ND & ND \\
\hline SW1 & 4 & $19 \cdot 0$ & 5 & ND & ND \\
\hline SW2 & 3 & $22 \cdot 0$ & 13 & ND & ND \\
\hline JR & 5 & $1 \cdot 4$ & 105 & + & ND \\
\hline KB & 1 & $6 \cdot 0$ & 92 & - & ND \\
\hline JD & 9 & $4 \cdot 0$ & 78 & ND & ND \\
\hline VE & 1 & $19 \cdot 0$ & 57 & + & ND \\
\hline $\mathbf{R F}$ & 7 & $4 \cdot 0$ & 140 & f. & ND \\
\hline HS & 3 & $3 \cdot 5$ & 47 & & ND \\
\hline MF & 3 & $2 \cdot 7$ & 54 & $\therefore$ & ND \\
\hline MB & 13 & $15 \cdot 0$ & 30 & + & ND \\
\hline CF & 3 & $10 \cdot 0$ & 70 & + & ND \\
\hline HW & 6 & $3 \cdot 0$ & 19 & ND & ND \\
\hline $\mathbf{S N}$ & 4 & $2 \cdot 8$ & 9 & - & 0.2 \\
\hline NS & 12 & 3.0 & 60 & + & 1.9 \\
\hline JS & 6 & $1 \cdot 5$ & 46 & + & 0 \\
\hline MR & 10 & $15 \cdot 0$ & 17 & + & $41 \cdot 8$ \\
\hline TL & 5 & $2 \cdot 0$ & 80 & - & ND \\
\hline $\mathbf{R A}$ & 2 & 8.0 & 206 & $+r$ & 192.7 \\
\hline Mean & 5 & $10 \cdot 0$ & 62 & & 59 \\
\hline
\end{tabular}

ND = not done. 
here there was a wider difference in values, six showing a score difference of more than $\mathbf{4 0}$ and two of more than 60 .

The acid phosphatase activity did not correlate with age, diagnostic white cell count, or periodic acidSchiff positivity. Four of the 33 patients tested with the heteroantibody to non-T, non-B ALL did not react with this, but all had acid phosphatase scores around the mean for their sex. There appeared to be an association between high TdT levels and high acid phosphatase scores, but this was not sufficiently apparent to be of statistical significance. All but one of the patients achieved complete remission after treatment, and only four have relapsed at the time of writing (three girls with acid phosphatase scores of 5,57 , and 78 , and one boy with a score of 81 ).

\section{Discussion}

It has been established by Catovsky et al..$^{4}$ that there is a clear association between $T$ lymphocytic membrane markers and strong acid phosphatase activity in the blast cells of patients with ALL. By those authors' criteria we agree that less than $10 \%$ of patients with non-T ALL show such strong positivity but feel that the sharp distinction into categories of acid phosphatase 'positive' or 'negative' cases is perhaps somewhat artificial as there is some, albeit less striking, enzyme activity present in the blast cells of the majority of patients. It is this weaker spectrum of activity in the non-T diseases that we have attempted to evaluate.

By using a scoring system similar to that used for alkaline phosphatase in neutrophils, we have not only confirmed our impression that the lymphoblasts of a large number of childhood non-T ALL's show an easily measurable degree of acid phosphatase, but we have also found that significantly higher levels of the enzyme are present in boys.

If acid phosphatase is a marker acquired early in the ontogeny of $T$ lymphocytes, as has been suggested, ${ }^{8}$ and if the enzyme is strongly positive in lymphoblasts with an incomplete T-ALL phenotype, as has been observed, ${ }^{9}$ our findings imply that boys are predisposed to develop a partially $\mathrm{T}$-differentiated sheep cell rosette negative ALL more frequently than girls. Considering that 'classical' T ALL is more common in males, ${ }^{10}$ this is perhaps not hard to imagine, and it is tempting to speculate that if the poor prognosis seen in $T A^{A L L}{ }^{10}$ is reflected to a lesser extent in ALL with an incomplete $T$ cell phenotype, as it apparently may be, ${ }^{9}$ the difference in prognosis between the sexes that has already been observed ${ }^{123}$ might be explained on these grounds.

If this hypothesis is correct then all non-T ALL patients with high acid phosphatase scores might be expected to show a worse prognosis than those with low scores, irrespective of sex. As only four of the 41 patients described have so far relapsed we cannot comment on whether this is so or not except to observe that as the sex difference in prognosis does not become apparent until two to three years after diagnosis, ${ }^{13}$ we would not expect to see any discernible difference in outlook emerging at this stage in a small series with a minimum follow-up time of three months. Likewise, no cases of testicular disease have emerged from the study group, so we cannot comment on any relationship there may be between acid phosphatase score at diagnosis and subsequent testicular disease. Time will tell on both these points. but what is already clear is that there seems to be a cytochemical difference between untreated male and female non-T childhood ALL.

We thank Dr MF Greaves for the anti-ALL antibody studies and Professor AV Hoffbrand for the TdT assays.

This study was supported by grants from the Trent Regional Health Authority and the Leukaemia Research Fund.

\section{References}

1 Baumer JH, Mott MG. Sex and prognosis in childhood acute lymphoblastic leukaemia. Lancet 1978:2: 128-9.

${ }^{2}$ Medical Research Council Working Party on Leukaemia in Childhood. Effects of varying radiation schedule, cyclophosphamide treatment, and duration of treatment in acute lymphoblastic leukaemia. $\mathrm{Br}$ Med J 1978;2:787-91.

${ }^{3}$ George SL, Aur RJA, Mauer AM, Simone JV. A reappraisal of the results of stopping therapy in childhood leukemia. $N$ Engl J Med 1979;300:269-73.

4 Catovsky D, Cherchi M, Greaves MF, Janossy G, Pain C, Kay HEM. Acid phosphatase reaction in acute lymphoblastic leukaemia. Lancet 1978:1: 749-51.

5 Janossy G, Greaves MF, Sutherland R, Durrant J, Lewis C. Comparative analysis of membrane phenotypes in acute lymphoid leukaemia and in lymphoid blast crisis of chronic myeloid leukaemia. Leuk Res 1977:1:289-300.

${ }^{6}$ Hoffbrand AV, Ganeshaguru K, Janossy G, Greaves MF, Catovsky D, Woodruff RK. Terminal deoxynucleotidyl-transferase levels and membrane phenotypein diagnosis of acute leukaemia. Lancet 1977:2: 520-3.

7 Goldberg AF, Barka T. Acid phosphatase activity in human blood cells. Nature 1962;195:297.

${ }^{8}$ Stein H, Müller-Hermelink HK. Simultaneous presence of receptors for complement and sheep red blood cells on human fetal thymocytes. Br J Haematol 1977; 36:225-30. 
9 Thiel E, Rodt H, Netzel B, Huhn D, Wündisch GF, Hass RJ, Bender-Götze C, Thierfelden S. T-ZellAntigen positive, E-Rosetten negative akute Lymphoblastenleukämie. Blut 1978;36:363-9.

${ }^{10}$ Chessells JM, Hardisty RM, Rapson NT. Acute lymphoblastic leukaemia in children: classification and prognosis. Lancet 1977;2:1307-9.

Requests for reprints to: Dr JS Lilleyman, Department of Haematology, The Children's Hospital, Western Bank, Sheffield S10 2TH, UK. 